\title{
An Analysis of Ship-Source Marine Pollution in Nigeria Seaports
}

\author{
D. E. Onwuegbuchunam ${ }^{1, *}$, T. E. Ebe ${ }^{2}$, L. I. Okoroji ${ }^{3}$ and A. E. Essien ${ }^{4}$ \\ 1 Department of Maritime Management Technology, Federal University of Technology, Owerri, Nigeria \\ 2 Department of Environmental Technology, Federal University of Technology, Owerri, Nigeria; \\ akumziri@gmail.com \\ 3 Department of Transport Management Technology, Federal University of Technology, Owerri, Nigeria; \\ okoroji_lazarus@yahoo.com \\ 4 West Atlantic Shipyard Ltd., Onne Port, Nigeria; abrahamessien@yahoo.com \\ * Correspondence: don@futo.edu.ng
}

Received: 20 May 2017; Accepted: 3 August 2017; Published: 23 August 2017

\begin{abstract}
Existing studies indicate that marine pollution control in the ports of developing economies is marred by a lack of administrative control and inadequate provision of waste reception facilities. In Nigeria ports, ship generated waste control services and provision of waste reception facilities are outsourced to private companies with no requirement for an activity audit. Apart from the port authority, other government agencies are also involved in pollution monitoring and control. Hence, functions are duplicated and effective regulation is arguably weakened by conflicts of interest. A scientific based integrated model is therefore proposed to address the managerial problem posed in the control of marine pollution in Nigerian ports. In this paper, we conduct a physico-chemical and microbiological analysis of samples of ships' wastewater to determine the status of marine pollution in the port environment. The samples were collected from randomly selected ships at berths in seaport locations. The outputs from the analysis are then integrated as inputs into an administrative framework model. The integrated model developed is proposed as an alternative administrative tool for monitoring and controlling pollution in seaports. The policy implications of the developed model are discussed.
\end{abstract}

Keywords: marine pollution; ship generated wastewater; physico-chemical and microbiological analysis

\section{Introduction}

The incidence of ship generated marine pollution has increasingly engaged the attention of the international maritime community in their effort to promote safe shipping and the protection of the marine environment. The growing concern about pollution centres on the potential for the shipping business to negatively impact the marine environment and the related biodiversity within the maritime field [1]. Ship-source marine pollutants emanate from cargo carried or waste generated onboard, which usually contains oil or oily mixtures and noxious substances. They accumulate from machinery operation or from the domestic activities of the crew living onboard. Additionally, shipborne pollutants include garbage, solid waste and antifouling paints on ship hulls [2]. Extant studies have documented the effects of ship based pollution on the marine environment. These include: the introduction of non-indigenous species to the aquatic environment (which threatens the sea animal population) and the negative effects on the economies of countries that depend on commercial fishing. For example, fisheries in the West African ecosystem generate some 500 million Euros annually and over 600,000 men and women depend directly on fishing and fishery related industries [3].

Against the backdrop of public concern and the need for mitigating policies, the shipping industry has actively sought to curtail the negative environmental effects arising from the shipping 
sector [1]. At an international level, various legal instruments and controls have been provided to encourage regulation and enforcement by flag states, coastal states and port state control. For example, the International Maritime Organization (IMO) convention on Marine Pollution MARPOL 73/78 outlines measures aimed at completely eliminating the willful and intentional discharge into the seas of oil and noxious or hazardous substances—chemicals, packaging, sewage and garbage. Specifically Annexes I, II, III, IV, V and VI of MARPOL 73/78 identify these sources and by their provision, port authorities are obligated to provide reception facilities for the handling of a range of waste including oil, chemical and garbage. Ports are also required to produce a Port Waste Management Plan, including information on the type and location of facilities, notification requirements, details of providers and costs. These plans are to be made available to port users, to ensure that vessels needs are met promptly with no undue delay.

The measures applied so far by IMO in terms of the conventions and their enforcement by flag state, coastal state and port state control have yielded fruitful results, especially in curtailing pollution from accidental spills arising from collisions [4]. However, pollution from non-accidental sources continues unabated and some port authorities have been found wanting regarding the provision of the requisite port waste reception facilities. The implication is that rising levels of marine pollution from ship based discharges are expected in these ports in the long run. For example, between the years 2008 and 2011, there were around 32\% and 18\% increases in the quantities of garbage and oily waste handled respectively in Nigeria's Tin Can Island port reception facilities alone [5].

\section{The Research Problem}

Lack of adequate waste reception facilities in developing countries' ports is such that vessels have no choice but to discharge waste at sea [6]. However, some vessel operators prefer to dump waste at sea, where there is a low risk of being caught, rather than use the provided facilities and thus pay the required user fees [7]. In West and Central African ports, facilities are becoming available in varying forms but remain inadequate hence ship waste collection processes in the ports are not only inefficient but also their management remains poor, [8]. In Nigeria for example, the Nigeria Ports Authority (NPA) - custodian of national ports does not own or operate waste reception facilities but outsources that responsibility to a private pollution control company. In the words of the port authority's managing director, Mohammed [9], the private pollution control company is to provide port reception facilities in all four navigational districts of Lagos, Port Harcourt, Warri and Calabar. The project is self-financing and contract tenure is 20 years beginning from the year 2006 [9]. In addition, this company is given the responsibility of monitoring waste discharge from vessels visiting the ports and reporting back to the authority. In this circumstance, no independent organization is put in place to audit the activities of pollution control contractors.

Against this backdrop, this paper proposes a practical model for monitoring and controlling ship-source marine pollution based on laboratory analysis of effects of pollutants on discharge areas within the harbour. Specifically, analysis of physico-chemical and microbiological properties of ship generated waste water would provide scientific information on the level of pollution (or its risk level) in the marine port environment. Integrated within the regulatory framework existing at the port, continuous scientific analysis of ships' berthing areas provides a robust model for monitoring and controlling marine pollution in the ports. In this study, we propose the analysis of ship generated wastewater as a proxy for the analysis of water quality in the berthing area exposed to pollution from ship-sources. A major assumption of this study therefore is that the analysis of the properties of wastewater collected at the source (ships at berth) provides a proxy medium for understanding the nature and extent of pollution in the port environment.

In the realisation of our major aim, our set objectives for this research are as follows:

- To determine the significant physico-chemical and microbiological parameters of ship generated wastewater from vessels berthed at the ports. 
- To compare the values of these parameters with Nigeria's Department of Petroleum Resources (DPR) standards for Effluent Discharge from marine vessels.

- To examine the significant effects of the parameters (by the type of wastewater) on the marine environment.

This study will be limited to the analysis of marine pollution from ships in the port environment, the environment of port pollution administration and the resulting implications for the administrative framework for controlling ship related marine pollution in seaports.

\section{Conceptual and Literature Review}

\subsection{Sources of Marine Pollution}

Article 1(4) of the 1982 United Nations Convention on the Law of the Seas (UNCLOS) defines pollution of the marine environment to mean the introduction by man, directly or indirectly, of substances or energy into the marine environment which are likely to result in negative effects on living resources, are hazardous to human health, a hindrance to marine activities including fishing and other legitimate uses of the sea, cause an impairment in quality for seawater uses and the reduction of amenities.

On a global scale it is generally recognised that marine pollution is mainly caused by human activities based on land and much less by human activity taking place at sea [10]. Specifically, shipping impacts on the marine environment in a number of ways and these according to reference [11] include:

- Pollution by oil and hazardous or toxic substances from incidental, operational and illegal discharges;

- Air pollution through emissions and particulate matter from engine exhaust gases and cargo tanks which may be carried over long distances;

- Discharge of operational waste from ships, including discharge of raw sewage and garbage (litter);

- Release of toxic chemicals used in anti-fouling paints and leaching of heavy metals from anodes;

- The introduction of non-indigenous organisms through ships' ballast water and associated sediments, and fouling on ships' hulls;

- Pollution and physical impact through loss of ships and cargo;

- Physical and other impacts including noise and collision with marine mammals.

The effects of these are mainly noticeable in busy shipping lanes and harbours; impact in or close to ecologically sensitive areas may be more significant in coastal areas [10]. Figure 1 classifies shipborne waste which may be discharged in deep sea, inland waters or at the ports in the absence of reception facilities.

This paper focuses on ship generated wastewater including ballast wastewater and wastewater from domestic activities of the crew living onboard. Accordingly, we have grouped ship generated wastewater by three basic types: bilge wastewater, black wastewater (sometimes grey wastewater is included to describe wastewater free from human faeces) and ballast wastewater, see also Figure 1 . These are described in the following sections: 


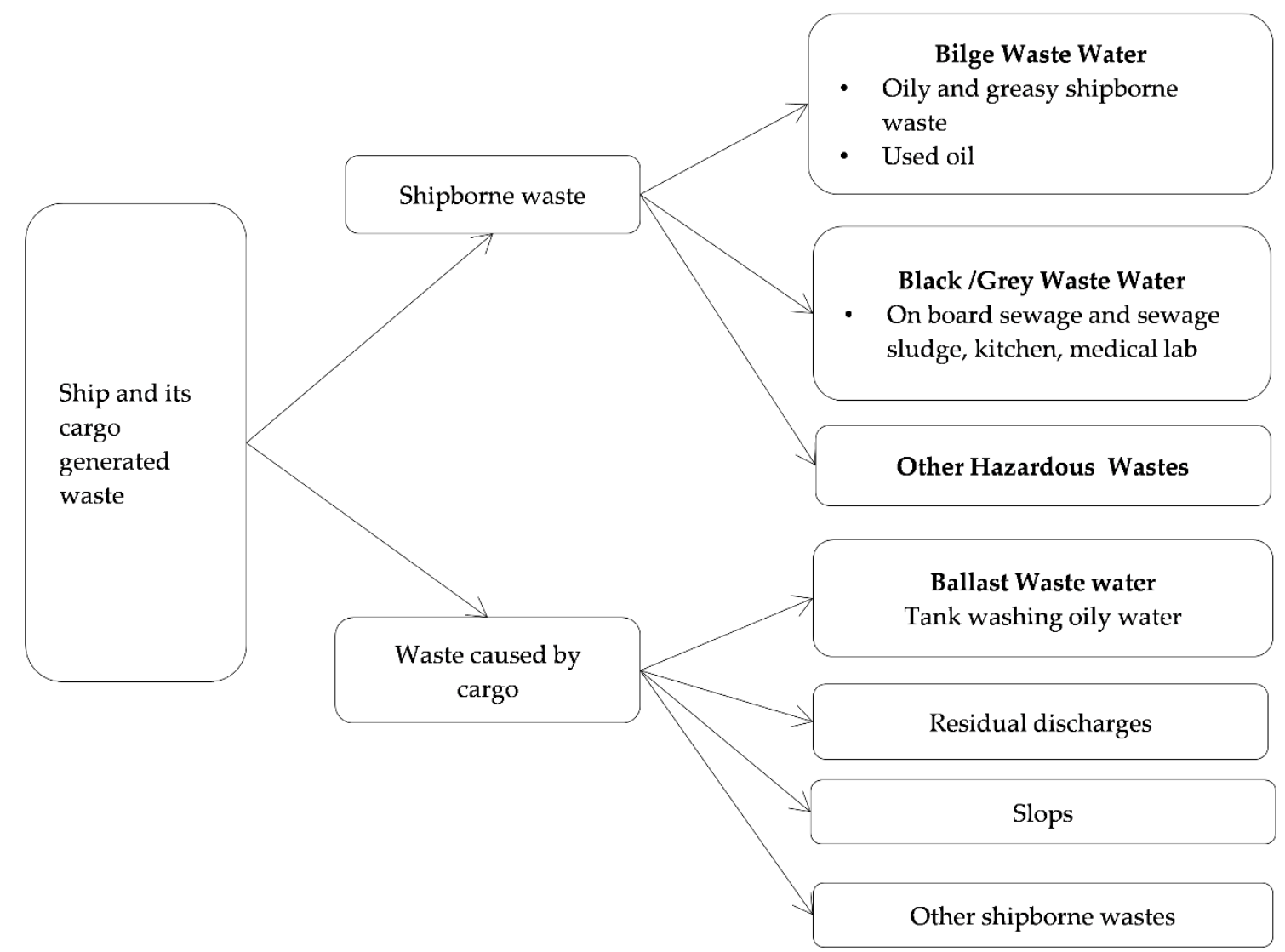

Figure 1. Classification of ship and cargo generated waste discharged in and out of the port environment. Source: adapted from ([12], cited by [13]).

\subsubsection{Black Waste Water}

Sewage from vessels also known as "black water", generally means human body wastewater from toilets and other receptacles intended to receive or retain bodily waste. The principal international convention addressing discharge standards for vessel sewage is Annex IV of the International Convention for the Prevention of Pollution from Ships (known as MARPOL 73/78, or simply MARPOL). MARPOL Annex IV contains regulations regarding: the discharge of sewage into the sea, ships' equipment and systems for the control of sewage discharge, the provision for facilities at ports and terminals for the reception of sewage, and the requirements for surveillance and certification. MARPOL Annex IV generally requires ships to be equipped with either a sewage treatment plant, a sewage comminuting and disinfecting system, or a sewage holding tank.

\subsubsection{Bilge Waste Water}

The bilge is the area where water from various operational sources in the ship collects. Bilge water is the mixture of water, oily fluids, lubricants, cleaning fluids and other similar waste that accumulate in the lowest part of a vessel from a variety of different sources including the main and auxiliary engines; boilers, evaporators and related auxiliary systems; equipment and related components; and other mechanical and operational sources found throughout the machinery spaces of a vessel. It is not uncommon on ships for oil or water to leak into the bilge from these sources: various seals, gaskets, fittings, piping, connections, and from related maintenance and activities associated with these systems. In addition to containing oil and grease, bilge water may contain solid waste such as rags, metal shavings, paint, glass and a variety of chemical substances. Bilge water may also contain various oxygen-demanding substances, volatile organic compounds, semi-volatile organics, inorganic salts and 
metals. O Depending on the types of ships visiting ports, the amount of bilge water which is delivered could fluctuate between 50 and 30,000 L per service. The number of services can be estimated at 2.4-3 disposal services per ship per year, see Table 1 , which means that about $9 \mathrm{~m}^{3}$ of bilge water are produced annually [13]. Bilge water regulations are contained in Annex I of the MARPOL 73/78 Convention.

Table 1. Average amount of bilge water for different types of vessels.

\begin{tabular}{cc}
\hline Type of Vessel & Average Amount of Bilge Water $\mathbf{~ ( ~}^{\mathbf{3}} /$ Service) \\
\hline Motorised Cargo Vessel & 3.7 \\
Tanker ships & 4 \\
Push boats & 3.5 \\
Passenger liner & 1.8 \\
\hline \multicolumn{2}{c}{ Source: ([12], cited by [13]). }
\end{tabular}

\subsubsection{Ballast Wastewater}

Ballast water is bunkered to stabilize vessels and regulate the draft. If necessary, it is discharged into the waterway long distances away from the origin source. Discharged ballast water could contain pathogens, and moreover be a travel medium for invasive species, which may reproduce rapidly under the new environmental conditions and become ecological pests [14]. Some of the non-indigenous organisms introduced to some countries through ballast water include: the Eurasian zebra mussel (Dreissena polymorpha), the American comb jelly (Mnemiopsis leidyi), the Japanese brown kelp (Undaria pinnatifida), the Japanese brown kelp (Undaria pinnatifida), Southeast Asian dinoflagellates of the genera Gymnodinium and Alexandrium, etc. [15]. These organisms have cost enormous resources in efforts to contain their negative impacts on the marine environment [16].

The IMO Ballast Water Management Convention (which came into force in the year 2005) delineates the measures that the signatory states must take to minimize risk to the environment, human health and resources from the transfer of harmful aquatic organisms and pathogens by ships' ballast water and sediment. It requires each state to develop national policies for ballast water management for ships, ports and waters under its jurisdiction. Each must ensure that ballast water sediment reception facilities are provided in the appropriate ports and terminals. So far, only a few countries have ratified the convention and they are: Barbados, Egypt, Kenya, Kiribati, Maldives, Mexico, Nigeria, Norway, Saint Kitts and Nevis, Sierra Leone, South Africa, Spain, the Syrian Arab Republic and Tuvalu [7].

\subsection{The International and Nigeria's Legal Framework for Controlling Marine Pollution}

The framework for the international legal regime for preventing vessel source pollution is described in the United Nations Convention on the Law of the Sea (UNCLOS). UNCLOS, provides the legislative and enforcement jurisdiction of a state over a particular vessel, but its application varies depending on whether the state is a flag, coastal or port state. The convention created a uniform system that seeks to safeguard the freedom of navigation and the interest of coastal states in protecting and preserving the marine environment within their jurisdiction [16]. In addition to UNCLOS, vessel source pollution is governed by the various conventions adopted by the International Maritime Organization (IMO). The global mandate of the IMO is implicitly acknowledged in UNCLOS through the expression "competent international organization". The IMO is responsible for setting the standards at an international level to prevent vessel source pollution. These include: discharge and emission, construction, design, equipment, manning and navigational standards. Parties to all IMO conventions are under obligation to domesticate the provisions of the conventions in their national laws. It is also expected that relevant government agencies or designated organizations are set up to enforce compliance to these laws.

In Nigeria, the scope of legal framework in place mainly covers prevention of oil pollution in the petroleum sector. Examples of these laws/Acts, according to a study by [17] are (a) Mineral Oil 
Safety Regulation 1963, (b) Oil in Navigable Waters Regulation 1968, (c) Petroleum Regulations 1967, (d) Petroleum (Drilling and Production) Regulation 1973, (e) Petroleum Refining Regulation 1974.

Other regulatory measures relating to pollution control can be inferred from the mandate of some of the Nigerian government parastatals established to regulate oil pollution. Examples include: the Federal Environmental Protection Agency (FEPA) (now part of Ministry of Environment), which issues standards for water, air, land quality and oil companies' operations, the Nigeria Department of Petroleum Resources (DPR), which issues Environmental Guidelines and Standards for the petroleum sector in Nigeria, and the National Oil Spill Detection and Response Agency (NOSDRA) whose mandate is to co-ordinate and implement the National Oil Spill Contingency Plan. The Nigeria Ports Authority (NPA) as the custodian of Nigerian ports has an institutional mandate to provide waste reception facilities. The authority maintains a pollution monitoring unit even though it has contracted out its waste management responsibility to a private company. However, the Nigeria Maritime Administration and Safety Agency (NIMASA) by the decree establishing it, appears to be the only parastatal with the specific mandate to ensure pollution prevention and control in the marine environment through implementation of domesticated IMO conventions. Thus, the administrative framework in place for controlling pollution in Nigeria depicts overlapping functions of the parastatals involved and represents a potential source of conflict, the discussion of which is beyond the scope of this paper.

\subsection{Review of Empirical Studies on Marine Pollution}

Few papers specifically examine the effects of marine pollution on marine resources in West African coastal regions, particularly Nigeria's ports and inland waters. Some of these studies concentrated on the identification of sources and their potential effects on the marine environment. Examples include [18] who identify sewage, industrial effluents, plastics that float on water and abandoned objects other than vessel-based ones, as sources. According to them, the specific effects of these sources on the marine environment include: degradation and thermal pollution which adversely affects the ecosystem. Others include: eutrophication arising from untreated waste which can kill sea animals, plants and cause the depletion of dissolved oxygen which affects Biochemical Oxygen Demand (BOD). These findings are consistent with [19]. A similar study [2] identified additional marine pollutants namely: oily water discharge from tanker accidents, accidental oil discharge during routine operations, wastewater, garbage and solid waste from vessels. Additional sources also include: ballast water or that from machinery spaces, exhausts and antifouling paints from vessel hulls.

However, other studies focused more on the examination of legislations and frameworks for enforcement of applicable conventions for the control of marine pollution. Notable ones include: [17], who studied the organizational and institutional framework of oil spillage and pollution management in Nigeria. Specifically they appraised the relevant laws (including international agreements) enacted by the government of Nigeria since 1963 which aim to mitigate the incidence of oil pollution. In addition, they also examined the relevant agencies established to implement procedures on oil pollution and management during oil prospecting/production activities. A similar paper [15], advocates for setting up a uniform system for managing shipborne waste. According to the authors such uniform frameworks would spell out uniform measures for collection and treatment of oil, greasy cargo and other ship waste.

In terms of challenges in implementation of prescriptions of relevant pollution control legislations, a companion paper [1] identifies the constraints in the enforcement of low sulphur marine regulation fuel within the Baltic and North Sea's Emission Control Areas (ECA's) (comprising UK and Sweden in particular). Marine fuel burnt in vessels operating within ECA's is limited to $0.1 \%$ sulphur content. Alternatively, sulphur abatement technologies should be employed where high sulphur content marine fuel is used. Their study demonstrates the weakness in enforcement measures based on paper work only and in the absence of analysis of water quality to confirm compliance.

Although the above reviews are limited, their findings are rather instructive considering the focus of the present study. For example, it has been established that pollution based on marine sources has negative impacts on marine resources which ultimately affects the economy of littoral states, see 
studies by [2,18]. Mitigation measures in the form of enforcement of IMO regulations have been hampered by the lack of effective and commonly acceptable frameworks for implementation; see $[1,18]$ and then [16] who advocate for a regional model of enforcement and provision of waste reception facilities and financing based on the electronic Vignette system. Yet, [8] contend that waste handling facilities in West and Central African countries are inadequate. This position is also consistent with [4]. The study by [6] however, posits that some developing countries face financial constraints in the provision of adequate waste handling facilities in their ports.

From the review, it is established among other challenges that adequate reception facilities and robust monitoring/control mechanisms are lacking in most countries' ports, Nigerian ports inclusive. For example the study by [1], identifies weakness in the pollution control framework model in place that does not account for prevailing pollution levels. This paper attempts to address current research gaps by proposing an integrated model for the management of pollution in marine port environments. The proposed model integrates a process of continuous analysis of water quality in the marine port environment using ship generated wastewater as a proxy. This model envisages an integrated approach that combines laboratory evidence and existing regulations to produce a framework that could be employed by port pollution control administrators.

\section{Materials and Methods}

The study locations consist of Nigerian port harbours (berthing areas). A berthing area is a body of water where ships are anchored temporarily while being loaded or discharged of their cargoes. Ships scheduled for cargo handling operations can be at anchor for more $24 \mathrm{~h}$ and seven working days in a week. This activity duration is considered sufficient time within which ship generated wastewater discharges can occur. Two ports namely Apapa $\left(6^{\circ} 26^{\prime} 43^{\prime \prime} \mathrm{N}, 3^{\circ} 25^{\prime} 34^{\prime \prime} \mathrm{E}\right)$ and Calabar $\left(4^{\circ} 58^{\prime} 0^{\prime \prime} \mathrm{N}\right.$, $8^{\circ} 19^{\prime} 26^{\prime \prime}$ E) were chosen as the study locations. Wastewater samples were collected from a sample of ocean going vessels (with Gross Registered Tonnage (GRT) exceeding 400 tons) anchored in the berthing areas within these ports.

\subsection{Sample Collection}

Nine waste samples (three samples of each type of wastewater) were collected from vessels berthed at different locations. The samples were: bilge wastewater, ballast wastewater, and black wastewater. These samples were collected with sterile $75 \mathrm{~cm}$ screwed top plastic bottles; they were stored in a temperature of $4{ }^{\circ} \mathrm{C}$. In order to avoid staleness of samples, some of the pollution indicator parameters were determined within six hours of sample collection.

\subsection{Laboratory Analysis}

The analyses covered physical, chemical and microbiological parameters of the wastewater samples. The parameters tested for were: $\mathrm{pH}$, temperature, conductivity, total dissolved solids, total suspended solids, turbidity, dissolved oxygen, biochemical oxygen demand, chemical oxygen demand, total oil and grease, copper, iron, lead, zinc, aluminium, cadmium, mercury, total coliform count, total heterotrophic bacteria, and total heterotrophic fungi.

\subsection{Determination of the Physico-Chemical and Microbiological Parameters}

Data collection utilized a sampling method whereby water samples from marine cargo vessels at berths were subjected to physico-chemical and microbiological analysis according to the American Public Health Association (APHA) method to determine the level of concentration of identified parameters. Standard procedures were applied to prepare our sample for the analysis. Thus, for the sake of brevity, we have in this section omitted the laboratory procedures which followed. These are however attached in Appendix A. In the following sections, we discuss the results from the analysis of our samples. Significant values of parameters obtained from the laboratory analysis are compared to the Department of Petroleum Resources (DPR) specified standards for effluent discharges from barges, 
ships and tankers working in inland or near shore waters. The DPR standards place limits on quantity and quality of effluent discharges from vessels to guard against: hazards to human health, harm to living organisms (fauna and flora) and aquatic life and impairment of quality of adjacent land, surface and ground waters. The implications of our findings are discussed.

\section{Presentation of Results}

The results of the laboratory analysis of the physico-chemical and microbiological properties of ship generated wastewater are presented in the following Figures 2-5 and in Table 2. In Table 2, we present the descriptive statistics of the physico-chemical and microbiological parameters of the sample investigated. Figures $2-5$ display the variability in values of parameters given the different types of wastewater: bilge, ballast and black water. Except for the trace metals, there was much variability in the parameter values of the physical, chemical and microbiological properties of the samples. This observation can be inferred from the error bars shown in the figures for the various samples of wastewater analysed. This variability is negligible and does not indicate the presence of outliers which could affect our conclusions.

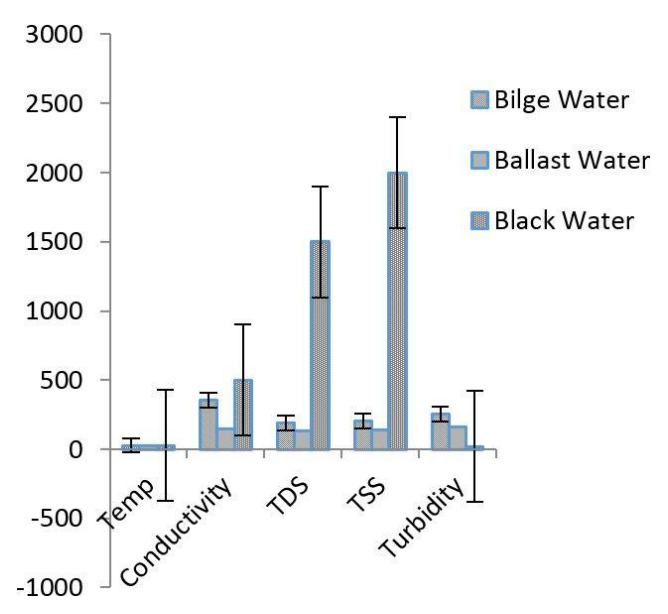

Figure 2. Distribution of the physical parameters of shipborne wastewater.

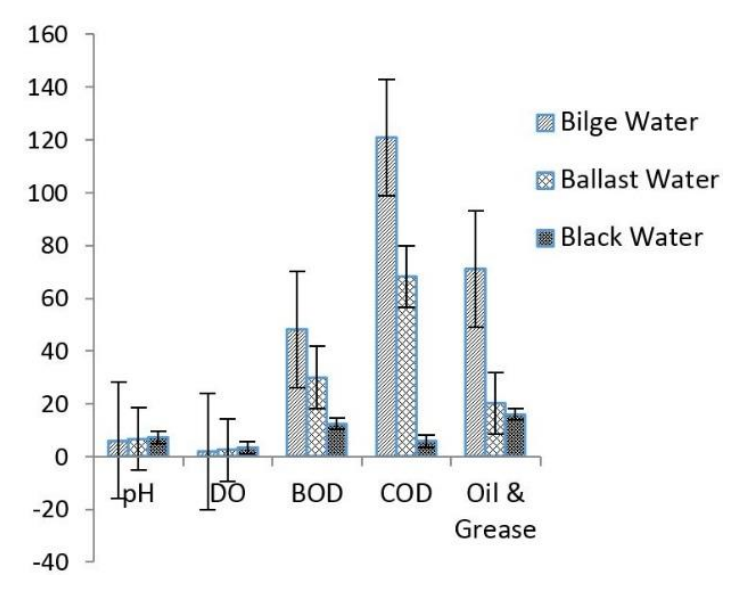

Figure 3. Distribution of the chemical parameters of shipborne wastewater. 


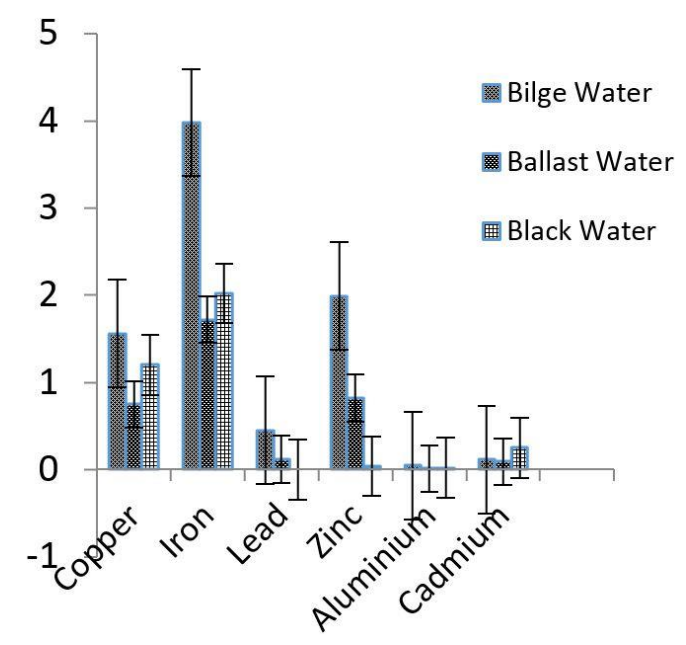

Figure 4. Distribution of the trace metal parameters of shipborne wastewater.

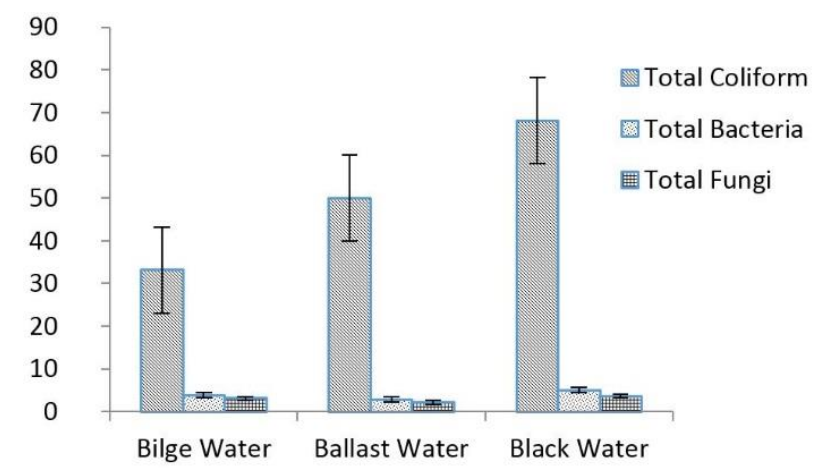

Figure 5. Distribution of the microbiological parameters of shipborne wastewater.

Table 2. Descriptive Statistics and Comparison of the Physico-chemical and Microbiological Parameters Obtained from the Department of Petroleum Resources (DPR) Nigeria, Specified Limits.

\begin{tabular}{|c|c|c|c|c|c|c|c|}
\hline Parameters & $\begin{array}{l}\text { Bilge } \\
\text { Water }\end{array}$ & $\begin{array}{l}\text { Ballast } \\
\text { Water }\end{array}$ & $\begin{array}{l}\text { Black } \\
\text { Waste }\end{array}$ & Mean * & $\begin{array}{l}\text { Std. Mean } \\
\text { Err. }\end{array}$ & $\begin{array}{l}\text { DPR * } \\
\text { Std. }\end{array}$ & $\begin{array}{c}\text { Significant } \\
\text { (Mean * > DPR } \\
\text { Limit) }\end{array}$ \\
\hline $\mathrm{pH}$ & 6.04 & 6.73 & 7.4 & 6.72 & \pm 0.28 & $6.5-8.5$ & No \\
\hline Temperature ${ }^{\circ} \mathrm{C}$ & 28.1 & 27.1 & 27.9 & 27.7 & \pm 0.216 & 30 & No \\
\hline Conductivity, $\mu \mathrm{S} / \mathrm{cm}$ & 356.8 & 150.1 & 500.01 & 335.6 & \pm 3.48 & 100 & Yes \\
\hline TDS, $\mathrm{mg} / \mathrm{L}$ & 189.04 & 130.2 & 1500 & 606.4 & \pm 5.79 & $<2000$ & No \\
\hline TSS, mg/L & 202 & 137.01 & 2000 & 779.67 & \pm 21.87 & 50 & Yes \\
\hline Turbidity, NTU & 256.9 & 160 & 20.6 & 145.8 & \pm 1.54 & 10 & Yes \\
\hline $\mathrm{DO}, \mathrm{mg} / \mathrm{L}$ & 2.01 & 2.5 & 3.39 & 2.63 & \pm 0.28 & 5.0 & No \\
\hline $\mathrm{BOD}, \mathrm{mg} / \mathrm{L}$ & 48.22 & 30 & 12.5 & 30.24 & \pm 7.30 & 30 & Yes \\
\hline $\mathrm{COD}, \mathrm{mg} / \mathrm{L}$ & 120.9 & 68.2 & 5.97 & 65.02 & \pm 40.68 & 40 & Yes \\
\hline Oil and Grease, $\mu \mathrm{g} / \mathrm{L}$ & 71.25 & 20.11 & 16.05 & 35.8 & \pm 12.57 & 48 & No \\
\hline Copper, $\mu \mathrm{g} / \mathrm{L}$ & 1.56 & 0.75 & 1.2 & 1.17 & \pm 0.21 & 1.5 & No \\
\hline Iron, $\mu \mathrm{g} / \mathrm{L}$ & 3.98 & 1.72 & 2.02 & 2.57 & \pm 40.75 & 0.3 & Yes \\
\hline Lead, $\mu \mathrm{g} / \mathrm{L}$ & 0.447 & 0.12 & n.a & 0.507 & \pm 0.11 & 0.05 & Yes \\
\hline Zinc, $\mu \mathrm{g} / \mathrm{L}$ & 1.99 & 0.82 & 0.04 & 0.95 & \pm 0.40 & 1.0 & No \\
\hline Aluminium, $\mu \mathrm{g} / \mathrm{L}$ & 0.045 & 0.01 & 0.02 & 0.025 & \pm 0.01 & 0.2 & No \\
\hline Cadmium, $\mu \mathrm{g} / \mathrm{L}$ & 0.113 & 0.09 & 0.25 & 0.151 & \pm 0.05 & 0.003 & Yes \\
\hline Mercury, $\mu \mathrm{g} / \mathrm{L}$ & n.a & n.a & n.a & n.a & n.a & 0.1 & n.a \\
\hline Total Coliform, MPN/100 mL & 1100 & 2500 & 4635 & 2745 & \pm 72.76 & - & n.a \\
\hline $\begin{array}{l}\text { Total Heterotrophic } \\
\text { Fungi, } \times 10^{5} \mathrm{cfu} / \mathrm{mL}\end{array}$ & 15.1 & 8.1 & 25.1 & 16 & \pm 6.98 & 100 & No \\
\hline $\begin{array}{c}\text { Total Heterotrophic } \\
\text { Bacteria, } \times 10^{6} \mathrm{cfu} / \mathrm{mL}\end{array}$ & 9.6 & 4.5 & 0.02 & 4.71 & \pm 1.96 & 100 & No \\
\hline
\end{tabular}

Source: Author, based on fieldwork. ${ }^{*}$ Extracts from DRP guidelines, n.a: not available. 


\subsection{Comparative Analysis of Physico-Chemical Parameters with the DPR Permissible Limit}

In Table 2, we carry out a comparative analysis of the mean values of the physico-chemical and microbiological parameters of ship wastewater samples with the limit outlined by the DPR for effluent discharges (for barges, ships and tankers). $\mathrm{pH}$ is an indicator of acidic or alkaline conditions of the water status. The observed value of $\mathrm{pH}(6.72 \pm 0.28)$, indicates that the ship wastewater sample is slightly acidic. The $\mathrm{pH}$ increased significantly with different types of ship wastewater and falls below the DPR permissible range. As the acidity of the surface water increases, submerged aquatic plants decrease depriving water fowl of their basic food source. Caustic soda from soaps and detergents from washed materials on board vessels may have been the cause of the increase in $\mathrm{pH}$ observed in different samples in this study.

Temperature $\left(27.7 \pm 0.216^{\circ} \mathrm{C}\right)$ increased significantly over different samples. The range falls within the DPR standards. The temperature difference in any aquatic habitat is affected by weather, and the extent of shade from direct exposure to sunlight [20]. Also, biodegradation of organic matter that enters the water may increase heat [20].

Conductivity values recorded in this study $(336 \pm 3.48 \mu \mathrm{S} / \mathrm{cm})$ are found to be above the DPR standards. The black wastewater sample recorded the highest value of $500.01 \mu \mathrm{S} / \mathrm{cm}$ of conductivity. The increase may be attributed to high levels of dissolved solids in the sample such as: chloride, phosphate and nitrate. It may also be as a result of the storage of the waste product onboard vessels. TDS increased significantly with different samples of ship wastewater with a mean of $606.4 \pm 5.79 \mathrm{mg} / \mathrm{L}$ which is below the DPR permissible limit for discharges in inland or near shore water. The observed high TSS in black wastewater could be attributed to the influx of non-biodegradable solids in the sample. Turbidity is associated with suspended solid concentrations; the turbidity range values recorded in this analysis were low in black wastewater and highest in bilge wastewater with a range of (160.0-256.9, $145.8 \pm 21.87)$ NTU which falls above the DPR permissible limit. The high turbidity recorded in bilge water can be attributed to leaks from the machinery equipment of the vessel as stated before in this study.

Dissolved oxygen (DO) is a measure of the degree of pollution by organic matter, the destruction of organic substances as well as the self-purification capacity of the water body. The DO of ship wastewater $(2.63 \pm 0.283 \mathrm{mg} / \mathrm{L})$ was lower than the DPR acceptable limit of $5.0 \mathrm{mg} / \mathrm{L}$. DO in liquid provides a source of oxygen needed for oxidation of organic matter when the concentration is high and a lack of it causes the water to become dead or void of aquatic life [21]. The mean value $(30.24 \pm 7.30 \mathrm{mg} / \mathrm{L})$ of BOD in ship wastewater was slightly above the DPR acceptable limit of $30 \mathrm{mg} / \mathrm{L}$, which means that discharging wastewater into the marine environment will affect the aquatic life and the ecosystem. The chemical oxygen demand (COD) recorded in this study $(26.7 \pm 30.35 \mathrm{mg} / \mathrm{L})$ was above the DPR standard of $40 \mathrm{mg} / \mathrm{L}$. Observed Iron $(\mathrm{Fe})$ values ranged from $1.72-3.98(2.57 \pm 40.75 \mathrm{mg} / \mathrm{L})$ and were found to be above the DPR permissible limit of $0.30 \mathrm{mg} / \mathrm{L}$. Iron values increased significantly with different samples of waste and were highest in bilge water. Copper $(1.17 \pm 0.206 \mathrm{mg} / \mathrm{L})$ was below the DPR permissible limit of $1.5 \mathrm{mg} / \mathrm{L}$.

Higher bacterial concentrations in sea are strongly linked to total coliform and faecal coliform. A high microbial population in an aquatic system is a reflection of the input of micro-organisms in ship wastewater discharged into the marine environment and the availability of growth supporting organic matter. High counts of bacterial load reflect the level of water pollution as it gives an indication of the amount of organic matter present [22]. The mean total bacterial counts as obtained in this study were remarkably high. Human waste and waste from machinery onboard the ship could be responsible for the high values of total coliform count and other parameters as observed in this study.

\subsection{Discussion of Results}

The findings from the laboratory analysis of ship wastewater samples based on the DPR criteria for water quality shows that the Nigerian seaport environment is polluted. This is occurring despite the pollution control legislation enforcement framework currently in place at the ports. A number of 
deductions are evident from this finding. It is possible that the pollution control contractors in place are not monitored for effective service delivery. Again, considering the multiplicity of pollution regulatory parastatals, effective monitoring may be lacking since it is not clear which should be the supervising parastatal. This is the prevailing situation that has informed this research which advocates for the building of a regulatory framework that incorporates scientific analysis for monitoring port pollution.

\subsection{Development of Integrated Pollution Control Model}

Having determined the significance of pollutants arising from ship generated wastewater in marine port environments, we discuss their implications for the development of an integrated framework for pollution monitoring and control. As pointed out in Section 2.2, the regulatory authorities namely: the Port Authority- NPA, NIMASA, FEPA (now FME), DPR and NOSDRA by the Acts establishing them, have a responsibility in the control of marine pollution. The overlap of functions existing among them presents areas of conflicts of interest. Given this setting, the port authority for example, is not in direct control of the pollution control framework in place since it uses a contracting company which is also self-monitoring. Thus, the present scenario casts doubt on outputs regarding pollution control in the ports. In this circumstance, outputs of scientific analysis of at-risk berthing areas would provide the basis for assessment and continuous improvement and hence complement the regulatory framework in place. Figure 6 articulates elements of the proposed hybrid model framework that combines regulatory laws with inputs derived from continuous laboratory analysis of water quality in berthing areas of the ports.

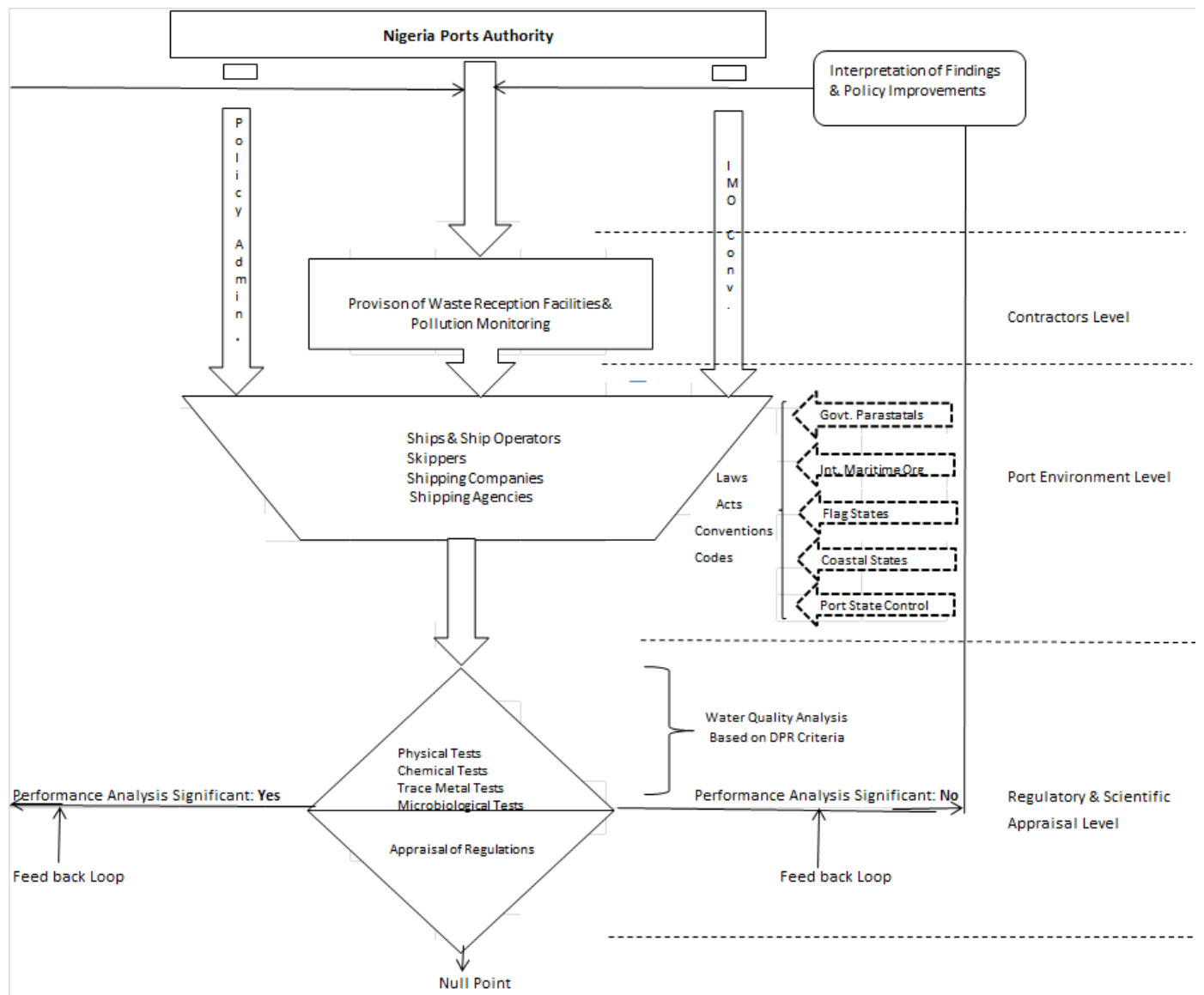

Figure 6. Elements of the integrated administrative framework model for marine pollution administration in ports. Source: author's own elaboration. 


\section{Conclusions}

In recognition of the overlapping and hence weak administrative framework for controlling marine pollution in port environments where provision of waste reception facilities is outsourced, we found evidence to propose the use of an integrative model that combines a legislative framework with input from continuous scientific analysis. Specifically, the port authority can apply this model framework, which is based on scientific evidence from laboratory analysis, to monitor the performance of its contractors. Considering the overlap of functions of other parastatals involved, the government of Nigeria can apply the model developed in this study to assess the effectiveness of the pollution control measures in the port sector.

\section{Recommendation}

Marine pollution management and administrative frameworks in Nigerian ports require evaluation for continuous improvement and should incorporate elements of scientific process. Given the multiplicity of organisations involved (i.e., the port authority and other agencies whose interests may potentially undermine results) the present paper proposed the adoption by the port authority of an integrated model for marine pollution administration in port environments. The federal government should institute a supervisory parastatal which would coordinate the activities of all the agencies with similar pollution control mandates. The physico-chemical and microbiological analyses were based on samples from two ports namely Apapa and Calabar ports. Thus, future research should expand to other ports to improve on the present findings.

Acknowledgments: This research was sponsored by the authors with no external support. Again, no support was received from any institution to cover cost of publishing in open access.

Author Contributions: Author 1 conceived the study, participated in the design and wrote the paper. Author 2 assisted in designing the methodology and supervised the laboratory analysis. Authors 3 and 4 did the field data collection and participated in the laboratory analysis.

Conflicts of Interest: The authors declare no conflict of interest.

\section{Appendix A}

\section{Procedures Followed in Preparation of the Sample Prior to the Analysis pH (APHA $4500 \mathrm{H}^{+}$)}

Measurements were carried out by means of a Horiba U-53 pH meter, which had been previously calibrated in the laboratory. Calibration was checked on the field by measuring standard buffer solutions. Calibration was repeated if reading was more than $\pm 5 \%$ of expected reading.

\section{Temperature}

This was determined by means of a mercury thermometer calibrated in $0.2{ }^{\circ} \mathrm{C}$ units from $0{ }^{\circ} \mathrm{C}$ to $100^{\circ} \mathrm{C}$. The thermometer was dipped into the sample and left for about $5 \mathrm{~min}$ for equilibration before the reading was recorded.

\section{Turbidity (APHA $213^{\circ}$ B)}

Turbidity of collected samples were analysed the same day using a Horiba U-53 multi-parameter water quality meter.

\section{Dissolved Oxygen}

The dissolved oxygen levels of the collected samples were analysed the same day using a Horiba U-53 multi-parameter water quality meter. 


\section{Conductivity/TDS (APHA-2540-C)}

Measurements were carried out by means of a Win Lab Conductivity/TDS meter, which was calibrated in the laboratory. Calibration was checked by measuring standard conductivity solutions.

\section{Total Dissolved Solids (TDS)}

TDS was determined according to APHA-2540-C, i.e., the instrumental method using the Horiba U-53 TDS meter TDS is reported in $\mathrm{mg} / \mathrm{L}$.

\section{Total Suspended Solids (APHA 2540-D)}

This was determined by filtering a well-mixed aliquot $(100 \mathrm{~mL})$ of the samples through a dried and pre-weighed Millipore filter paper using a vacuum filtration apparatus. The filter papers were then dried at $105^{\circ} \mathrm{C}$ to a constant weight. The difference in weight of the filter papers represents the total suspended solids. This was reported in $\mathrm{mg} / \mathrm{L}$ after calculation.

\section{Heavy Metals (APHA 3030 E)}

The concentrations in $\mathrm{mg} / \mathrm{L}$ of heavy metals in the collected samples were determined (after nitric acid digestion) by means of an Atomic Absorption Spectrophotometer (Biotech Engineering, Phoenix 986-UK). $100 \mathrm{~mL}$ of the water sample was measured and $5 \mathrm{~mL}$ of nitric acid was added (Nitric acid digestion) into a beaker. The sample was placed on a hot plate and heated in a fume hood until white fumes evolved. The digested sample was allowed to cool and was filtered into a $100 \mathrm{~mL}$ volumetric flask and made up to the mark with de-ionized water. The sample was then transferred to a $100 \mathrm{~mL}$ plastic can for AAS analysis.

\section{Mercury}

Mercury was analysed by the cold vapour method (APHA 3112-B) while the remaining metals were analysed by the direct air-acetylene flame method (APHA 3111-B). Specific metal standards (Accu Standards, New Haven, CT, USA) in the linear range of the metal were used to calibrate the equipment. The concentrated and digested samples were then aspirated and the actual concentrations were obtained by referring to the calibration graph and necessary calculations, the result was reported in $\mathrm{mg} / \mathrm{L}$.

\section{Chemical Oxygen Demand (APHA 5220 B)}

The COD was determined using the open reflux method (APHA 1992), where a sample is refluxed and digested in a strongly acidic solution with a known amount of excess of potassium dichromate $\left(\mathrm{K}_{2} \mathrm{Cr}_{2} \mathrm{O}_{7}\right)$. After digestion, the excess un-reacted potassium dichromate was read with a spectrophotometer (Lamotte Smart 3, LaMotte Company, Chestertown, MD, USA) at $600 \mathrm{~nm}$ and the results were reported in $\mathrm{mg} / \mathrm{L}$. Results were also verified by titrating with a standard solution of Ferrous Ammonium Sulphate (FAS).

\section{Biochemical Oxygen Demand (APHA 5210B)}

The BOD, which depends on oxygen uptake by bacteria, was determined using the dilution method according to APHA 5210B (APHA 1992). The amount of oxygen consumed during a fixed period (usually five days) is related to the amount of organic matter present in the original sample. The dissolved oxygen of the samples was first determined using the WinLab Dissolved Oxygen meter (WinLab 196363, Germany) and then incubated for five days at $20^{\circ} \mathrm{C}$. The DO was again measured after a period of five days and BOD in $\mathrm{mg} / \mathrm{L}$ was determined from the following calculation and reported accordingly.

$\mathrm{BOD}=[\mathrm{DOB}-\mathrm{DOA}]-[\mathrm{DOSB}-\mathrm{DOSA}] \mathrm{D}$ 
Where

$\mathrm{D}=$ dilution factor usually 0.5

$\mathrm{DOB}=\mathrm{DO}$ of sample before incubation

$\mathrm{D}=\mathrm{DO}$ of sample after incubation

DOSB $=$ DO of sample blank before incubation

DOSA $=$ DO of sample blank after incubation

\section{Oil and Grease (API-RP45)}

Oil and Grease was determined according to API-RP45 method using a Spectrophotometer. The sample was extracted twice with 1:10 ratio of Xylene to sample using a separator funnel. The combined extract after centrifuging was read in the spectrophotometer using Xylene as the reference material t $400 \mathrm{~nm}$ wavelength. Readings obtained from the spectrophotometer were traced out on the calibration graph and used to calculate the concentration of oil and grease in $\mathrm{mg} / \mathrm{L}$ in the sample.

\section{Total and Faecal Coliform}

Total coliform bacteria were determined using the Multiple Tube Fermentation Technique expressed as Most Probable Number (MPN) APHA 9222C. A $10 \mathrm{~mL}$ water sample was dispensed into a $10 \mathrm{~mL}$ sterile double strength Mac Conkey broth in test tubes containing inverted Durham tubes for gas collection. A $1 \mathrm{~mL}$ water sample was also dispensed into $5 \mathrm{~mL}$ single strength Mac Conkey broth (sterile) in test tubes incorporated with inverted Durham tubes. To another three sets of test tubes containing $5 \mathrm{~mL}$ sterile single strength Mac Conkey broth to which inverted Durham tubes had been incorporated, $0.1 \mathrm{~mL}$ of the water sample was dispensed. All tubes were incubated at $37^{\circ} \mathrm{C}$ for $24 \mathrm{~h}$. The numbers of coliform organisms present were determined by the presence of gas and acid using the most probable number table. Results were expressed in MPN/100 mL.

\section{Total Heterotrophic Bacteria and Fungi}

Heterotrophic bacteria and fungi were estimated by the aerobic standard plate count (Pour Plate technique). Serial dilutions of the samples were performed using sterile peptone water as diluents. The sample $(1.0 \mathrm{~mL})$ was transferred aseptically into $9.0 \mathrm{~mL}$ sterile peptone water to give a 10-fold dilution (10-1). The bottle containing peptone water and the sample was vigorously shaken and allowed to stand for a minimum of $5 \mathrm{~min}$. Further dilutions were carried out until a desired dilution factor (10-3) was achieved which depends on the source of the sample. Aliquot $(0.1 \mathrm{~mL})$ of the dilution fold of 10-3 was used to inoculate sterile Petri dishes in duplicates. Sterile molten nutrient agar was then aseptically poured (Pour Plate Method) into a sterile plate to support bacterial growth while Sabouraud dextrose agar was used for fungi growth with the addition of acid. The culture plate were allowed to solidify and then inverted, followed by incubation at $28^{\circ} \mathrm{C} \pm 2.0^{\circ} \mathrm{C}$ for $24 \mathrm{~h}$. Sabouraud dextrose agar plates were incubated at the same temperature for 3-4 days.

After incubation, the culture plates were counted (Total Viable Count (TVC)) and the results calculated thus:

$$
C f u=\frac{T V C \times \text { dilution factor }}{\text { Innoculum Vol. }}
$$

Final results obtained were expressed in $\mathrm{Cfu} / \mathrm{mL}$

\section{Precautions Taken on Media Preparation}

- Accurate weighing of powder and water measurement was ensured.

- The powder and water mixture was covered with a cotton wool (wrapped with an aluminum foil to prevent moisture accumulation on wool) plug as soon as possible to prevent contamination.

- The media on preparation and dishes were sterilized in the autoclave at $121^{\circ}$ for $15 \mathrm{~min}$. 
- The media were allowed to cool to a certain temperature before pouring into plates to avoid steam formation on plates which contain contamination.

\section{References}

1. Helen, S.; Bloor, M.; Baker, S.; Dahlgren, K. Greener shipping? A consideration of the issues associated with the introduction of emission control areas. Marit. Policy Manag. 2016, 43, 295-308.

2. Umo, I.; Nitonye, S. Effects and Solutions of Marine Pollution from Ships in Nigerian Waterways. Int. J. Sci. Eng. Res. 2015, 6, 81-90.

3. Kloff, S.; Wicks, C. Environmental Management of Offshore Oil Development and Maritime Oil Transport: A Background Document for Stakeholders of the West African Marine Eco Region. A Research Report by IUCN Commission on Environmental, Economic and Social Policy. 2004. Available online: http://cmsdata.iucn. org/downloads/offshore_oil_eng.pdf. (accessed on 10 February 2017).

4. Szepes, M. MARPOL 73/78: The Challenges of Regulating Vessel-Source Oil Pollution. Manch. Stud. Law Rev. 2013, 2, 73-109.

5. Momoh, B.C. An Investigation on Ship Generated Waste in Tin Can Island Port. Unpublished Thesis, Nigeria Institute of Safety, 2013. Available online: https:/ / www.academia.edu/14642108/An_Investigation_on_ Ship_Generated_Waste_in_Tin_Can_Island_Port (accessed on 14 March 2017).

6. Carpenter, A. The Reduction of Ship-Generated Waste in the North Sea: A Contemporary Analysis. Unpublished Ph.D. Thesis, University of Leeds, Leeds, UK, 2005.

7. Anstey, F. Ballast Water Management: A Time for Action. 2008. Available online: http://web.deu.edu.tr/ maritime/imla2008/Papers/36.pdf (accessed on 23 March 2017).

8. Barns-Dabban, H.; Koppen, K.V.; Mol, A. Environmental Reform of West and Central Africa Ports: The Influence of Colonial Legacies. Marit. Policy Manag. 2017, 44, 565-583. [CrossRef]

9. Mohammed, A.S. Port Development in Nigeria, International Symposium on Maritime Economy and Transport Services in West and Central Africa Countries. 2009. Available online: http:/ /www.nigerianports. org/dynamicdata/uploads/MD (accessed on 10 March 2017).

10. Group of Experts on the Scientific Aspects of Marine Environmental Protection. Ocean at Risk? GESAMP Statement of 1998 Concerning Marine Pollution Problems. 1999. Available online: http://gesamp.imo.org/ ocean.htm (accessed on 2 March 2017).

11. Ware, K. Assessment of the Impacts of Shipping on the Marine Environment. A Research Report Presented to OSPAR Commission. 2009. Available online: http://qsr2010.ospar.org/media/assessments/p00440_ Shipping_Assessment.pdf (accessed on 24 March 2017).

12. Donau, V. Danube Ports. 2010. Available online: http://www.danubeports.info (accessed on 31 May 2012).

13. Berger, H. Waste Management for Inland Navigation on the Danube. 2012. Available online: http://www. donauschiffahrt.de/de/100078442/unsere_flotte.html (accessed on 28 March 2017).

14. ICES, International Council for the Exploration of the Sea. Report on the Ices Advisory Committee on the Marine Environment. Copenhagen, 1994. Available online: http:/ /ices.dk/sites/pub/Publication\%20Reports/ Cooperative\%20Research\%20Report\%20(CRR)/crr239/CRR239.pdf (accessed on 22 February 2017).

15. Berger, H.; Horvat, I.; Simongáti, G. Ship Waste Management along the Danube: The Way towards an International Danube Ship Waste Convention. Waste Manag. Environ. 2014, 180, 53-64.

16. Liu, N.; Maes, F. Prevention of Vessel-Source Marine Pollution: A Note on the Challenges and Prospects for Chinese Practice under International Law. Ocean Dev. Int. Law 2011, 42, 356-367. [CrossRef]

17. Kadafa, A.A.; Zakaria, M.P.; Othman, F. Oil Spillage and Pollution in Nigeria: Organizational Management and Institutional Framework. J. Environ. Earth Sci. 2012, 2, 22-30.

18. Elenwo, E.I.; Akankali, J.A. The Effects of Marine Pollution on Nigerian Coastal Resources. J. Sustain. Dev. Stud. 2015, 8, 209-224.

19. Bouaoun, D.; Nabbout, R. Study of Physical and Chemical Parameters of Oustouan River, North Lebanon. J. Coast. Zone Manag. 2016, 19, 1-8. [CrossRef]

20. Ekhaise, F.O.; Anyasi, C.C. Influence of Breweries Effluent Discharge on the Microbiological and Physicochemical Quality of Ikpoba River, Nigeria. Afr. J. Biotechnol. 2005, 4, 1062-1065. 
21. Chukwu, O. Analysis of Groundwater Pollution from Abattoir Waste in Minna, Nigeria. Res. J. Diary Sci. 2008, 2, 74-77.

22. Crowther, J.; Kay, D.; Wyer, M.D. Relationships between Microbial Water Quality and Environmental Conditions in Coastal Recreational Water: The Fylde Coast, UK. Water Res. 2001, 35, 4029-4038. [CrossRef] 